\title{
Vitamin D deficiency is common in psychogeriatric patients, independent of diagnosis
}

Ole Grønli ${ }^{1,2,3^{*}}$, Jan Magnus Kvamme ${ }^{1,2}$, Rolf Jorde ${ }^{1,2}$ and Rolf Wynn ${ }^{1,2}$

\begin{abstract}
Background: Previous studies have found an association between psychiatric disorders and vitamin D deficiency, but most studies have focused on depression. This study aimed to establish the prevalence of vitamin D deficiency in elderly patients with a wider range of psychiatric diagnoses.
\end{abstract}

Method: The study included elderly patients (>64 years) referred to a psychiatric hospital in Northern Norway and a control group from a population survey in the same area. An assessment of psychiatric and cognitive symptoms and diagnoses was conducted using the Montgomery and Aasberg Depression Rating Scale, the Cornell Scale for Depression in Dementia, the Mini Mental State Examination, the Clockdrawing Test, and the Mini International Neuropsychiatric Interview (MINI+), as well as clinical interviews and a review of medical records. The patients' mean level of 25-hydroxyvitamin $\mathrm{D}(25(\mathrm{OH}) \mathrm{D})$ and the prevalence of vitamin $\mathrm{D}$ deficiency were compared with those of a control group, and a comparison of vitamin $\mathrm{D}$ deficiency across different diagnostic groups was also made. Vitamin D deficiency was defined as $25(\mathrm{OH}) \mathrm{D}<50 \mathrm{nmol} / \mathrm{L}(<20 \mathrm{ng} / \mathrm{ml})$.

Results: The mean levels of $25(\mathrm{OH}) \mathrm{D}$ in the patient group $(n=95)$ and the control group $(n=104)$ were $40.5 \mathrm{nmol} / \mathrm{L}$ and $65.9 \mathrm{nmol} / \mathrm{L}(\mathrm{p}<0.001)$, respectively. A high prevalence of vitamin $\mathrm{D}$ deficiency was found in the patient group compared with the control group (71.6\% and 20.0\%, respectively; $\mathrm{p}<0.001)$. After adjusting for age, gender, season, body mass index, and smoking, vitamin D deficiency was still associated with patient status (OR: $12.95, \mathrm{Cl}$ (95\%): $6.03-27.83, p<0.001$ ). No significant differences in the prevalence of vitamin $D$ deficiency were found between patients with different categories of psychiatric diagnoses, such as depression, bipolar disorders, psychosis, and dementia.

Conclusion: Vitamin D deficiency is very common among psychogeriatric patients, independent of diagnostic category. Even though the role of vitamin D in psychiatric disorders is still not clear, we suggest screening for vitamin $D$ deficiency in this patient group due to the importance of vitamin $D$ for overall health.

\section{Background}

There has been an increase in interest in vitamin D deficiency over the last 10 years. Several studies have revealed a high prevalence of vitamin D deficiency even in areas of the world that receive ample sunlight. The level of 25-hydroxyvitamin D (25(OH)D) is used to evaluate subjects' vitamin D status. In Australia, India, and Saudi Arabia, $30-50 \%$ of children and adults have $25(\mathrm{OH}) \mathrm{D}$ levels below $50 \mathrm{nmol} / \mathrm{L}$ [1-3]. Similarly, in Norway, more than $40 \%$ of the population have been reported to have serum 25(OH)D levels below $50 \mathrm{nmol} / \mathrm{L}$ [4]. Only a few

\footnotetext{
* Correspondence: ole.gronli@unn.no

'Department of Clinical Medicine, Faculty of Health Sciences, University of Troms $\varnothing$, Troms $\varnothing$, Norway

${ }^{2}$ University Hospital of North Norway, Tromsø, Norway

Full list of author information is available at the end of the article
}

types of food naturally contain vitamin D (e.g., salmon, mackerel, and cod liver oil); therefore, the major source of vitamin D is sunlight [5]. UVB radiation in the 290$315 \mathrm{~nm}$ wavelength converts 7-dehydrocholesterol in the skin to previtamin D3, which, in turn, is converted into vitamin D3. Vitamin D3 is then hydroxylated in the liver to $25(\mathrm{OH}) \mathrm{D}$ and further hydroxylated in the kidneys to its active form, 1,25 dihydroxyvitamin $\mathrm{D}\left(1,25(\mathrm{OH})_{2} \mathrm{D}\right)$ [6]. Latitude and season affect the quantity and quality (wavelength) of solar radiation and thus influence the ability of sunlight to synthesize vitamin D3 in the skin [7]. For example, in Edmonton, Canada $\left(52^{\circ} \mathrm{N}\right)$, skin exposed to sunlight from October through March produced no previtamin D3 [7]. Previous studies showed that elderly individuals produce only $25 \%$ of the cutaneous vitamin $\mathrm{D}$ produced by young adults [8]. 
There has been some debate concerning the optimal range of $25(\mathrm{OH}) \mathrm{D}$. Serum levels of $25(\mathrm{OH})$ D below $50 \mathrm{nmol} / \mathrm{L}$ are associated with an increase in serum parathyroid hormone (PTH) levels [9] and a decrease in physical performance in older individuals [10]. It has been suggested that serum $25(\mathrm{OH}) \mathrm{D}$ levels above $50 \mathrm{nmol} / \mathrm{L}$ are sufficient to sustain bone density and calcium absorption and to prevent osteomalacia [11]. This cut-off level is now widely used in studies of vitamin $\mathrm{D}$ deficiency.

Several cross-sectional studies have found an association between vitamin $\mathrm{D}$ deficiency and depression or depressive symptoms [12-16]. Despite some negative reports [17], Anglin et al. [18] concluded in a recent metaanalysis that low vitamin D concentration is associated with depression, but further randomized controlled trials (RCTs) of vitamin D are needed to determine whether this association is causal. There have been a few RCTs studying the effects of vitamin $\mathrm{D}$ on depressive symptoms, but the findings are inconsistent [19-21]. A recently published RCT did investigate the effects of vitamin D supplementation as adjuvant treatment in patients with major depressive disorder. The results showed a significant improvement in patients being treated with an antidepressant and vitamin D as compared with patients receiving an antidepressant and placebo [22]. There are also studies reporting an association between vitamin $\mathrm{D}$ deficiency and cognitive impairment [23-25] and even psychosis has been associated with vitamin $\mathrm{D}$ deficiency [26-28].

Psychogeriatric patients may be at risk for vitamin D deficiency due to their age, less exposure to sunlight, and dietary factors. However, there is little knowledge regarding the actual vitamin $\mathrm{D}$ status in this group of patients. Therefore, one aim of this study was to compare the level of $25(\mathrm{OH}) \mathrm{D}$ in a sample of psychogeriatric patients with the level in the general elderly population from the same area. In addition, the study aimed to examine whether patients with depression differ from patients with other psychiatric diagnoses with regard to vitamin D status.

\section{Methods}

\section{Study population}

The study took place from March 2010 to December 2011. Patients aged 65 years or older who were referred to a psychiatric hospital located in Tromsø $\left(69^{\circ} \mathrm{N}\right)$ in the northern part of Norway were eligible for inclusion. The hospital has a population base of 255,000 subjects. Patients who were not able to communicate due to their medical condition (i.e., severe dementia) were excluded. With regard to the controls, subjects older than 64 years who had participated in a follow-up study after the 6th Tromsø study and had normal glucose tolerance were randomly selected and stratified for gender, age, BMI, and blood sampling season.

\section{Measures}

\section{Assessment of psychiatric symptoms}

The following instruments were used to diagnose the participant patients: the Mini International Neuropsychiatric Interview (MINI+) [29], the Montgomery-Asberg Depression Rating Scale (MADRS) [30], the Mini Mental Status Examination (MMSE) [31], and the Clockdrawing Test [32]. In addition to the structured diagnostic psychiatric interview (MINI+), clinical interviews and medical records were also used to diagnose the participants. Patients with dementia $(n=19)$ who could not participate in a MADRS interview were assessed with the Cornell Scale for Depression in Dementia [33]. Diagnoses were made according to ICD-10 criteria (WHO, 1992). The control group was not assessed for the presence of psychiatric disorders.

\section{Laboratory analyses}

Blood samples for $25(\mathrm{OH}) \mathrm{D}$ were drawn in the morning before 10 AM during the first 3 days of the hospital stay and were stored at $-70^{\circ} \mathrm{C}$. Analyses of $25(\mathrm{OH})$ D were performed using a competitive radioimmunoassay (RIA) (Dia Sorin, Stillwater, MN) [34]. Vitamin D deficiency was defined as $25(\mathrm{OH}) \mathrm{D}$ levels $<50 \mathrm{nmol} / \mathrm{L}$. In addition, analyses of calcium, albumin, PTH, creatinine, erythrocyte sedimentation rate (ESR), C-reactive protein (CRP), glucose, free thyroxine (FT4), and TSH were performed the same day.

\section{Statistical analyses}

The SPSS 20 software package (SPSS Inc., Chicago, Illinois, USA) was used for statistical analyses. The KolmogorovSmirnov test was used to confirm assumptions of normal distributions. Baseline differences were analyzed using chisquare tests (dichotomous data), Mann-Whitney U-test and independent samples t-tests (continuous data). Logistic regression models were used to assess the association between vitamin $\mathrm{D}$ deficiency and the sample variables (patient vs. control), controlling for potential confounders. The results were expressed as odds ratios (ORs) with 95\% confidence intervals (CIs). The association of vitamin D deficiency status with psychiatric diagnoses was examined using the Fisher's exact test. A correlation between PTH and $25(\mathrm{OH}) \mathrm{D}$ was calculated using Pearson's correlation method. A $p$-value $<0.05$ was accepted as statistically significant. The data are presented as the mean (SD) unless otherwise specified.

\section{Ethics and consent}

Possible candidates for inclusion in the study were given oral and written information about the study. The next 
of kin was given similar information if a patient was unable to provide informed consent alone due to his/her medical condition. Written consent (from the patient or the next of kin) was provided prior to inclusion in the study. Existing guidelines were used to assess competency to give consent [35]. The Regional Medical Ethics Committee for North Norway (REK North) approved the study.

\section{Results}

\section{Clinical characteristics}

A total of 95 patients (90 inpatients and 5 outpatients) and 104 controls were included in the study, all of whom were ethnic Norwegians. Basic characteristics of the patient and control groups are shown in Table 1. The patients suffered from a range of disorders that are typical in a psychogeriatric population (Table 2). We found that 40 patients had a depressive disorder, either as a firsttime depressive episode, recurrent depression or as part of a bipolar disorder. We also identified 18 patients with depression secondary to other diagnoses (e.g., dementia or organic mood disorder). In 37 of the patients no depressive disorders were identified. In this sub-group, 18 patients had dementia (14 with Alzheimer's disease), 11 patients had a psychotic disorder, and 8 patients had other non-depressive disorders.

\section{Serum 25(OH)D levels}

The mean (SD) serum 25(OH)D levels were 40.5 (19.0) $\mathrm{nmol} / \mathrm{L}$, which was significantly lower than the control group's of $65.9(19.5) \mathrm{nmol} / \mathrm{L}(\mathrm{t}(198)=-9.19, p<0.001)$. In the patient group, 68 patients $(71.6 \%)$ had vitamin $\mathrm{D}$ deficiency (serum 25(OH)D $<50 \mathrm{nmol} / \mathrm{L}$ ), as compared with only 21 individuals $(20.0 \%)$ in the control group $\left(\mathrm{X}^{2}=53.7, \mathrm{p}<0.001\right)$. Severe vitamin $\mathrm{D}$ deficiency $(25$ $(\mathrm{OH}) \mathrm{D}<25 \mathrm{nmol} / \mathrm{L})$ was observed in 18 patients $(19.4 \%)$ and 2 individuals $(1.9 \%)$ in the control group $(\mathrm{p}<0.001)$.

There was no significant gender difference between the mean $25(\mathrm{OH}) \mathrm{D}$ levels neither in the patient group (women: $40.7 \mathrm{nmol} / \mathrm{L}$, men: $40.3 \mathrm{nmol} / \mathrm{L}$ ) or in the control group (women: $63.3 \mathrm{nmol} / \mathrm{L}$, men: $69.4 \mathrm{nmol} / \mathrm{L}$ ). In a multivariate model that included age, gender, BMI,

Table 1 Clinical characteristics of the patient and control groups

\begin{tabular}{llll}
\hline & Patients & Controls & $\boldsymbol{p}$-value \\
\hline Gender \% (female/male) & $63.2 / 36.8$ & $62.9 / 37.1$ & $p=0.965^{*}$ \\
Age, mean (SD) & $77.2(6.5)$ & $74.6(1.3)$ & $p=0.002^{* *}$ \\
Smoking (\%) & 29.3 & 17.1 & $p=0.042^{*}$ \\
BMl (kg/m²), mean (SD) & $25.3(5.4)$ & $25.9(4.1)$ & $p=0.330^{* * *}$ \\
Blood sampling season (winter, & & & \\
spring, summer, autumn) (\%) & $18 / 28 / 26 / 27$ & $25 / 28 / 28 / 20$ & $p=0.515^{*}$ \\
\hline
\end{tabular}

Notes: ${ }^{*} X^{2}=$ Chi-square test, ${ }^{* *}$ Mann-Whitney U-Test, ${ }^{* * *}$ Student's t-test.
Table 2 Diagnoses of the 95 patients participating in the study

\begin{tabular}{ll}
\hline Diagnoses & $\mathbf{N}$ \\
\hline Dementia & \\
Alzheimer's & 20 \\
Vascular & 7 \\
Other dementia & 4 \\
Other organic mental disorders & 4 \\
& \\
Depressive episode & 5 \\
Recurrent depression & 26 \\
Bipolar affective disorders & \\
Depression & 8 \\
Manic & 2 \\
Psychotic disorders & 12 \\
Anxiety disorders & 4 \\
Other diagnoses & 3 \\
\hline
\end{tabular}

smoking, and blood sampling season, only patient status and blood sampling season were predictive of vitamin D deficiency (Table 3).

\section{Serum 25(OH)D levels and psychiatric diagnoses}

In the patient group, we did not find any significant difference in 25(OH)D levels between patients with depression as the main diagnosis, patients with depression as part of other diagnoses, and patients with another psychiatric diagnosis (Figure 1). Furthermore, when grouping the patients into five diagnostic categories (unipolar depression, bipolar depression, psychosis, dementia, and other diagnoses), there were still no significant differences in serum 25(OH)D levels between the groups (Table 4). There was a small, but significant correlation between MADRS score and serum 25(OH)D levels $\left(\mathrm{r}_{\mathrm{s}}=.26\right.$, $\mathrm{p}=0.028)$.

Table 3 Adjusted odds ratio $(95 \% \mathrm{Cl})$ for the association between vitamin $D$ deficiency and patient/control status

\begin{tabular}{lll}
\hline & OR $(\mathbf{9 5 \%} \mathbf{C l})$ & $\boldsymbol{p}$ \\
\hline Patient/control & $12.95(6.03-27.83)$ & $p<0.001$ \\
Sex & $1.55(0.76-3.16)$ & $p=0.231$ \\
Age & $0.99(0.92-1.07)$ & $p=0.876$ \\
Winter* & $p=0.067$ \\
Spring & $0.61(0.23-1.62)$ & $p=0.319$ \\
Summer & $0.27(0.10-0.75)$ & $p=0.012$ \\
Autumn & $0.36(0.13-1.04)$ & $p=0.060$ \\
BMl & $0.94(0.87-1.83)$ & $p=0.085$ \\
Smoking & $0.79(0.34-1.83)$ & $p=0.581$ \\
\hline Notes: ${ }^{*}$ season for blood sampling. &
\end{tabular}

Notes: *season for blood sampling. 


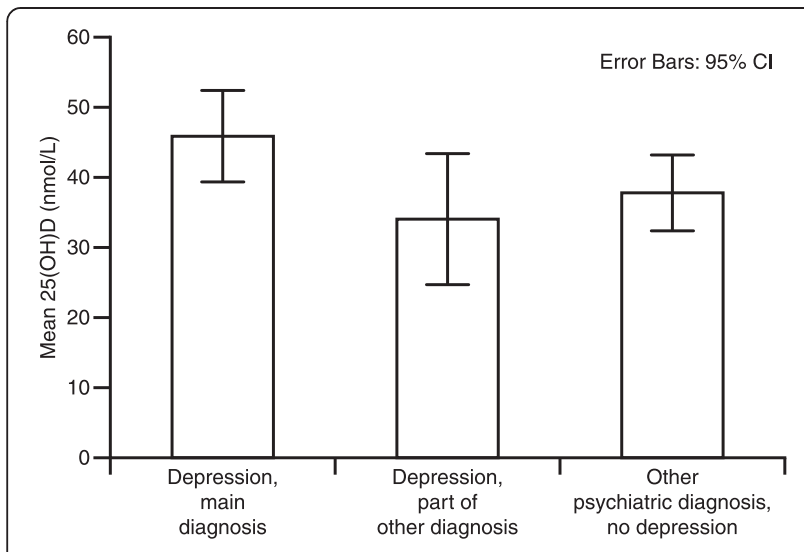

Figure 1 Serum 25(OH)D levels (nmol/L) in subjects with depression, comorbid depression, and other psychiatric diagnoses.

In the patient group, we had data on vitamin D sources used, namely, cod fish oil (a common supplement in Norway), vitamin D tablets (multivitamin), or vitamin D-fortified milk. We found that 39 patients (41\%) took some type of vitamin D supplement, 44 patients (46\%) did not take any supplement, and vitamin D source data were missing for 12 patients. There was no significant difference in 25(OH)D levels between the patient group that reported an intake of extra vitamin $\mathrm{D}$ and the group with no intake of extra vitamin D (mean 25(OH)D levels were $42.2 \mathrm{nmol} / \mathrm{L}$ and $36.2 \mathrm{nmol} / \mathrm{L}$, respectively). Furthermore, there was no significant association between vitamin $\mathrm{D}$ deficiency and intake of a vitamin D supplement. We also had data on the average time spent outdoors over the 3 months before study inclusion. There was no significant difference in 25(OH)D levels between patients who spent less than $30 \mathrm{~min}$ outdoors every day $(\mathrm{n}=61$, mean serum $25(\mathrm{OH}) \mathrm{D}=39.5 \mathrm{nmol} / \mathrm{L}(17.2))$ and patients who spent more than 60 min outside every day $(\mathrm{n}=17$, serum $25(\mathrm{OH}) \mathrm{D}=34.0 \mathrm{nmol} / \mathrm{L}(14.0))$. As expected, there were seasonal variations in vitamin $\mathrm{D}$ status, with higher levels present in summer and autumn. This result was a trend in both the patient and control

Table 4 Serum 25(OH) D levels and prevalence of vitamin $D$ deficiency in relation to diagnoses

\begin{tabular}{llll}
\hline Diagnoses & N & $\mathbf{2 5}(\mathbf{O H})$ level (nmol/L) & $\begin{array}{l}\text { Prevalence (\%) of } \\
\text { vitamin D deficiency }\end{array}$ \\
\hline Depression & 31 & $45.9(20.5)$ & 71.0 \\
Bipolar disorder & 10 & $43.8(18.0)$ & 50.0 \\
Psychosis & 12 & $33.9(16.0)$ & 83.3 \\
Dementia & 31 & $38.6(18.6)$ & 74.2 \\
Other diagnoses & 11 & $34.8(17.6)$ & 72.7
\end{tabular}

${ }^{1} \mathrm{~A}$ one-way ANOVA test revealed no significant difference $(F(4,90)=1.41$, $p=0.236)$ in $25(\mathrm{OH}) \mathrm{D}$ levels between the different diagnostic groups. ${ }^{2}$ The Fisher's exact test indicated no significant association $\left(x^{2}=3.1, p=0.522\right)$ between vitamin $\mathrm{D}$ deficiency and diagnosis. groups (Figure 2), but the differences in serum $25(\mathrm{OH}) \mathrm{D}$ level between different seasons were not statistically significant.

A total of $26 \%$ of the patients had elevated PTH levels $(>7.5 \mathrm{pmol} / \mathrm{L})$, and there was a negative correlation between serum 25(OH)D and PTH levels $(r=-0.34, p<$ 0.001). We did not have data on PTH in the control group. Neither the correlation between serum 25(OH)D levels and MMSE $\left(r_{s}=-.11, p=0.297\right)$ or with Clockdrawing Test scores in the patient group $\left(\mathrm{r}_{\mathrm{s}}=.07, \mathrm{p}=\right.$ 0.508) were significant.

\section{Discussion}

In this study, we found a high prevalence $(71.6 \%)$ of vitamin D deficiency in elderly psychiatric patients compared with a control group (19.2\%). We could not find any difference in vitamin D deficiency between patients in different diagnostic groups. Although this study was conducted in the northern part of Norway, vitamin D deficiency is a common problem in other parts of the world as well. Van der Wielen et al. found that among the elderly, vitamin D deficiency was more common in southern Europe than in Scandinavia [36]; therefore, our findings seem to be relevant globaly.

Our results are in line with those of other studies. In a group of psychogeriatric inpatients, Lapid et al. found no association between $25(\mathrm{OH}) \mathrm{D}$ level and psychiatric diagnosis [37], and the same findings were reported in a non-elderly group [38]. A Swedish study of adult psychiatric outpatients reported low levels of $25(\mathrm{OH}) \mathrm{D}$ (median $45 \mathrm{nmol} / \mathrm{L}$ ), with slightly lower levels in patients with schizophrenia and autism compared with other diagnoses [39]. However, we are not aware of any studies that have examined the difference in levels of $25(\mathrm{OH}) \mathrm{D}$ between a control group and psychogeriatric patients with a wide range of psychiatric disorders.

There are several possible explanations for our findings. On the one hand, it is possible that older individuals with

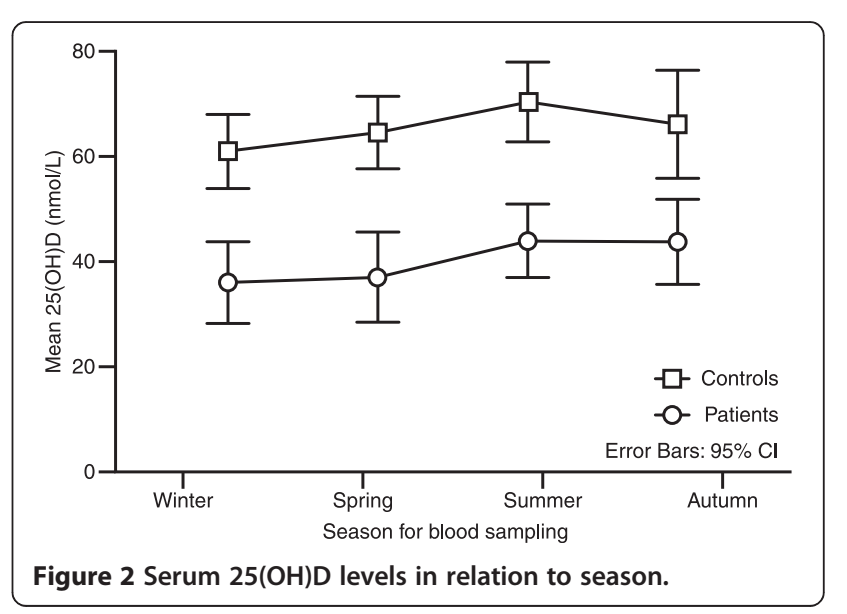


psychiatric disorders have a diet and outdoor activity pattern that may result in vitamin D deficiency, which could also be the case for different diagnostic groups, not only depressed patients. The hospital associated with this study is located at high latitude in the northern part of Norway, where there is no sun-induced production of vitamin $\mathrm{D}$ in the skin for more than 6 months of the year [7]. This patient group could thus be even more vulnerable to vitamin $\mathrm{D}$ deficiency due to a diet low in vitamin D. On the other hand, one cannot rule out the possibility that vitamin D deficiency can contribute to the development of several psychiatric disorders. It is well known that a diversity of psychiatric symptoms can occur in connection with various medical conditions. Some patients with thyrotoxicosis develop depression, others develop anxiety or psychosis, and some do not develop psychiatric disorders at all [40]. The same pattern is found in patients with hyperparathyroidism [41] and in patients with low levels of vitamin B12 [42]. These results suggests that there could be some unknown individual factors that make some people more vulnerable than others to the development of various psychiatric symptoms due to alterations in these hormones and micronutrients. Although we could not find a significant difference in serum 25(OH)D levels between different diagnostic groups, we can not rule out the possibility of a type II error, due to modest number of subjects in some of our diagnostic sub-groups.

Several human and animal studies have suggested possible biological explanations for the importance of vitamin D in psychiatric disorders. Vitamin D receptors and the enzyme required for its activation, $1 \alpha$ hydroxylase, have been identified in the human brain [43]. Active vitamin $\mathrm{D}\left(1,25(\mathrm{OH})_{2} \mathrm{D}\right)$ is shown to alter cholinergic, dopaminergic, and noradrenergic neurotransmitter systems in animal models [44]. Abnormalities of these neurotransmitters have been linked to various neuropsychiatric disorders [45]. Groves et al. studied the impact of adult vitamin D deficiency in two strains of mice [46], and a small reduction in an enzyme involved in GABA synthesis (GAD65/67) was reported. Altered GABAergic neurotransmission has been linked to several psychiatric conditions, including schizophrenia [47], anxiety [48], and depression [49]. In the most neophobic strain (BALB/c mice), Groves et al. also found alterations in glutamate and glutamine levels in brain tissue, which may indicate a disruption in glutaminergic neurotransmission. NMDA receptor (glutamate receptor) dysfunction has been linked to several psychiatric conditions, including depression and schizophrenia [50,51].

As expected, there was a significant negative correlation between serum $25(\mathrm{OH}) \mathrm{D}$ and PTH levels $[9,52]$. High levels of PTH have been associated with impaired performance in cognitive tests [53] and with depression [52]. Primary hyperparathyroidism with elevated PTH and calcium can present with a variety of psychiatric symptoms [41], and we previously reported that this may be due to elevated PTH and not elevated calcium [54]. It is therefore possible that an effect of vitamin D on psychiatric symptoms could be indirectly caused by elevated PTH levels.

There was no significant difference in vitamin $D$ levels between patients who reported taking a vitamin D supplement and patients who reported not taking a vitamin D supplement. These data are based on patients' selfreporting and thus it is difficult to draw any firm conclusions. However, the finding could strengthen the impression that the recommended supplement dose of vitamin $\mathrm{D}$ in Norway (400 IE vitamin $D_{3}$ ) is not enough to maintain an adequate level of vitamin $\mathrm{D}$ in elderly individuals, and several authors have recommended $800-1000$ IE vitamin $D_{3}$ as a daily supplement for the elderly $[6,55,56]$.

Although the role of vitamin D in psychiatric disorders is not clear, there are also other reasons to be aware of vitamin $\mathrm{D}$ deficiency. A meta-analysis of 17 randomised trials demonstrated a $12 \%$ risk reduction in fractures in patient groups receiving calcium and vitamin D supplements [57]. Vitamin D deficiency can cause proximal muscle weakness and muscle pain [58]. Vitamin D supplements increase muscle strength and balance and reduce the risk of falling $[59,60]$. In observational studies, vitamin D deficiency has also been associated with an increased risk of several other conditions, including cancer, diabetes, and multiple sclerosis, as well as a higher overall mortality rate and premature aging [6,61-63]. However, a recent review by Autier et al., found that intervention studies did not show an effect of vitamin D supplementation on non-skeletal health outcome whereas observational studies did. An exception was slightly reduced all-cause mortality [64]. The authors proposed that this difference in outcome might indicate that low $25(\mathrm{OH}) \mathrm{D}$ is a marker for ill health [64].

Our current study has some limitations. A reverse causality cannot be ruled out in this type of study design, as we do not know whether vitamin $D$ deficiency is a contributor or a consequence of psychiatric disorders. In the control group, we did not have data to assess medical comorbidity, and therefore, we were not able to control for ill health as a possible confounder. We did not have data on the amount of time spent outdoors, use of vitamin D supplements, or psychiatric symptoms in the control group. It is unlikely, however, that elderly patients with significant mental distress participated in the population survey. Hansen et al. found that non-attendees in a survey had a 2.5 -fold higher prevalence of psychiatric disorders compared with attendees [65]. In the patient group, there may also have been some recollection bias when the patients were asked about vitamin D supplementation and time spent outdoors. 


\section{Conclusions}

Although our study did not address the issue as to whether the observed differences represent a causal relationship between vitamin D deficiency and psychiatric symptoms, the results are nonetheless important given the significance of vitamin D to overall health. We suggest that increased attention should be given to vitamin $\mathrm{D}$ deficiency in elderly patients with psychiatric disorders. Serum 25(OH)D assessment should be included in the set of standard blood tests performed in this patient group and treatment with vitamin $\mathrm{D}$ should be initiated in patients with low serum $25(\mathrm{OH}) \mathrm{D}$. There is mounting evidence suggesting that vitamin $\mathrm{D}$ could have an impact on a variety of psychiatric conditions; however, more RCTs are needed to address the question of causality.

\section{Competing interests}

The authors declared that they have no competing interests.

\section{Authors' contributions}

OG and RW designed the study. OG collected the data and conducted the data analyses. RJ, RW and JMK contributed to the interpretation of the data. OG wrote the first draft of the manuscript. RJ, RW and JMK reviewed and revised the manuscript. All authors have read and approved the final version of the manuscript.

\section{Acknowledgement}

We are grateful to the laboratory staff at the Department of Laboratory Medicine, University Hospital of North Norway for their contributions to this study. We also thank the participating patients.

The study was funded by Northern Norway Regional Health Authority.

\section{Author details}

'Department of Clinical Medicine, Faculty of Health Sciences, University of Tromsø, Troms $\varnothing$, Norway. ${ }^{2}$ University Hospital of North Norway, Troms $\varnothing$, Norway. ${ }^{3}$ Department of Geriatric Psychiatry, UNN-Åsgård, Tromsø N-9291, Norway.

Received: 8 November 2013 Accepted: 28 April 2014

Published: 8 May 2014

\section{References}

1. Sedrani SH: Low 25-hydroxyvitamin D and normal serum calcium concentrations in Saudi Arabia: Riyadh region. Ann Nutr Metab 1984, 28(3):181-185

2. McGrath JJ, Kimlin MG, Saha S, Eyles DW, Parisi AV: Vitamin D insufficiency in south-east Queensland. Med J Aust 2001, 174(3):150-151.

3. Marwaha RK, Tandon N, Reddy DR, Aggarwal R, Singh R, Sawhney RC, Saluja B, Ganie MA, Singh S: Vitamin D and bone mineral density status of healthy schoolchildren in northern India. Am J Clin Nutr 2005, 82(2):477-482.

4. Mai XM, Chen Y, Camargo CA Jr, Langhammer A: Cross-sectional and prospective cohort study of serum 25-hydroxyvitamin $D$ level and obesity in adults: the HUNT study. Am J Epidemiol 2012, 175(10):1029-1036.

5. Holick MF, Chen TC: Vitamin D deficiency: a worldwide problem with health consequences. Am J Clin Nutr 2008, 87(4):1080S-6S.

6. Holick MF: Vitamin D deficiency. N Engl J Med 2007, 357(3):266-281.

7. Webb AR, Kline L, Holick MF: Influence of season and latitude on the cutaneous synthesis of vitamin D3: exposure to winter sunlight in Boston and Edmonton will not promote vitamin D3 synthesis in human skin. J Clin Endocrinol Metab 1988, 67(2):373-378.

8. Holick MF, Matsuoka LY, Wortsman J: Age, vitamin D, and solar ultraviolet. Lancet 1989, 2(8671):1104-1105.

9. Lips P: Vitamin D deficiency and secondary hyperparathyroidism in the elderly: consequences for bone loss and fractures and therapeutic implications. Endocr Rev 2001, 22(4):477-501.
10. Wicherts IS, van Schoor NM, Boeke AJ, Visser M, Deeg DJ, Smit J, Knol DL, Lips P: Vitamin D status predicts physical performance and its decline in older persons. J Clin Endocrinol Metab 2007, 92(6):2058-2065.

11. Institute of Medicine: Dietary reference intakes for calcium and vitamin D. Washington, DC: The National Academies Press; 2011.

12. Wilkins $\mathrm{CH}$, Sheline $\mathrm{Yl}$, Roe CM, Birge SJ, Morris JC: Vitamin D deficiency is associated with low mood and worse cognitive performance in older adults. Am J Geriatr Psychiatry 2006, 14(12):1032-1040.

13. Milaneschi $Y$, Shardell M, Corsi AM, Vazzana R, Bandinelli S, Guralnik JM, Ferrucci L: Serum 25-hydroxyvitamin D and depressive symptoms in older women and men. J Clin Endocrinol Metab 2010, 95(7):3225-3233.

14. Stewart R, Hirani V: Relationship between vitamin D levels and depressive symptoms in older residents from a national survey population. Psychosom Med 2010, 72(7):608-612.

15. Lee DM, Tajar A, O'Neill TW, O'Connor DB, Bartfai G, Boonen S, Bouillon R, Casanueva FF, Finn JD, Forti G, Giwercman A, Han TS, Huhtaniemi IT, Kula K, Lean ME, Punab M, Silman AJ, Vanderschueren D, Wu FC, Pendleton N: EMAS study group: lower vitamin $D$ levels are associated with depression among community-dwelling European men. J Psychopharmacol 2011, 25(10):1320-1328.

16. Kjaergaard $M$, Joakimsen $R$, Jorde R: Low serum 25-hydroxyvitamin D levels are associated with depression in an adult Norwegian population. Psychiatry Res 2011, 190(2-3):221-225.

17. Zhao G, Ford ES, Li C, Balluz LS: No associations between serum concentrations of 25-hydroxyvitamin $\mathrm{D}$ and parathyroid hormone and depression among US adults. Br J Nutr 2010, 104(11):1696-1702.

18. Anglin RE, Samaan Z, Walter SD, McDonald SD: Vitamin D deficiency and depression in adults: systematic review and meta-analysis. Br J Psychiatry 2013, 202:100-107.

19. Lansdowne AT, Provost SC: Vitamin D3 enhances mood in healthy subjects during winter. Psychopharmacology (Berl) 1998, 135(4):319-323.

20. Jorde R, Sneve M, Figenschau Y, Svartberg J, Waterloo K: Effects of vitamin D supplementation on symptoms of depression in overweight and obese subjects: randomized double blind trial. J Intern Med 2008, 264(6):599-609.

21. Kjaergaard M, Waterloo K, Wang CE, Almas B, Figenschau Y, Hutchinson MS, Svartberg J, Jorde R: Effect of vitamin D supplement on depression scores in people with low levels of serum 25-hydroxyvitamin D: nested case-control study and randomised clinical trial. Br J Psychiatry 2012, 201(5):360-368.

22. Khoraminya N, Tehrani-Doost M, Jazayeri S, Hosseini A, Djazayery A: Therapeutic effects of vitamin $D$ as adjunctive therapy to fluoxetine in patients with major depressive disorder. Aust N Z J Psychiatry 2013, 47(3):271-275

23. Buell JS, Scott TM, Dawson-Hughes B, Dallal GE, Rosenberg $I H$, Folstein MF, Tucker KL: Vitamin D is associated with cognitive function in elders receiving home health services. J Gerontol A Biol Sci Med Sci 2009, 64(8):888-895.

24. Annweiler C, Schott AM, Allali G, Bridenbaugh SA, Kressig RW, Allain P, Herrmann FR, Beauchet $O$ : Association of vitamin D deficiency with cognitive impairment in older women: cross-sectional study. Neurology 2010, 74(1):27-32.

25. Llewellyn DJ, Lang IA, Langa KM, Melzer D: Vitamin D and cognitive impairment in the elderly U.S. population. J Gerontol A Biol Sci Med Sci 2011, 66(1):59-65

26. Berg AO, Melle I, Torjesen PA, Lien L, Hauff E, Andreassen OA: A crosssectional study of vitamin $D$ deficiency among immigrants and Norwegians with psychosis compared to the general population. J Clin Psychiatry 2010, 71(12):1598-1604.

27. Hedelin M, Lof M, Olsson M, Lewander T, Nilsson B, Hultman CM, Weiderpass E: Dietary intake of fish, omega-3, omega- 6 polyunsaturated fatty acids and vitamin $D$ and the prevalence of psychotic-like symptoms in a cohort of 33,000 women from the general population. BMC Psychiatry 2010, 10:38. 244X-10-38.

28. Itzhaky D, Amital D, Gorden K, Bogomolni A, Arnson Y, Amital H: Low serum vitamin $D$ concentrations in patients with schizophrenia. Isr Med Assoc J 2012, 14(2):88-92.

29. Sheehan DV, Lecrubier Y, Sheehan KH, Amorim P, Janavs J, Weiller E, Hergueta T, Baker R, Dunbar GC: The mini-international neuropsychiatric Interview (M.I.N.I.): the development and validation of a structured 
diagnostic psychiatric interview for DSM-IV and ICD-10. J Clin Psychiatry 1998, 59(20):22-33. quiz 34-57.

30. Montgomery SA, Asberg M: A new depression scale designed to be sensitive to change. Br J Psychiatry 1979, 134:382-389.

31. Folstein MF, Folstein SE, MCHugh PR: Mini-mental state: a practical method for grading the cognitive state of patients for the clinician. J Psychiatr Res 1975, 12(3):189-198.

32. Shulman Kl: Clock-drawing: is it the ideal cognitive screening test? Int J Geriatr Psychiatry 2000, 15(6):548-561.

33. Alexopoulos GS, Abrams RC, Young RC, Shamoian CA: Cornell scale for depression in Dementia. Biol Psychiatry 1988, 23(3):271-284.

34. Grimnes $G$, Almaas B, Eggen AE, Emaus N, Figenschau Y, Hopstock LA, Hutchinson MS, Methlie P, Mihailova A, Sneve M, Torjesen P, Wilsgaard T, Jorde R: Effect of smoking on the serum levels of 25-hydroxyvitamin D depends on the assay employed. Eur J Endocrinol 2010, 163(2):339-348.

35. Pedersen R, Hofmann B, Mangset M: Patient autonomy and informed consent in clinical practice. Tidsskr Nor Laegeforen 2007, 127(12):1644-1647.

36. van der Wielen RP, Lowik MR, van den Berg H, de Groot LC, Haller J, Moreiras O, van Staveren WA: Serum vitamin D concentrations among elderly people in Europe. Lancet 1995, 346(8969):207-210.

37. Lapid MI, Drake MT, Geske JR, Mundis CB, Hegard TL, Kung S, Frye MA: Hypovitaminosis D in psychogeriatric inpatients. J Nutr Health Aging 2013, 17(3):231-234

38. Schneider B, Weber B, Frensch A, Stein J, Fritz J: Vitamin D in schizophrenia, major depression and alcoholism. J Neural Transm 2000 107(7):839-842.

39. Humble MB, Gustafsson S, Bejerot S: Low serum levels of 25-hydroxyvitamin $\mathrm{D}(25-\mathrm{OHD})$ among psychiatric out-patients in Sweden: relations with season, age, ethnic origin and psychiatric diagnosis. J Steroid Biochem Mol Biol 2010, 121(1-2):467-470

40. Stern RA, Robinson B, Thorner AR, Arruda JE, Prohaska ML, Prange AJ Jr: A survey study of neuropsychiatric complaints in patients with graves' disease. J Neuropsychiatry Clin Neurosci 1996, 8(2):181-185.

41. Chan AK, Duh QY, Katz MH, Siperstein AE, Clark OH: Clinical manifestations of primary hyperparathyroidism before and after parathyroidectomy: a case-control study. Ann Surg 1995, 222(3):402-12. discussion 412-4.

42. Lachner C, Steinle NI, Regenold WT: The neuropsychiatry of vitamin B12 deficiency in elderly patients. J Neuropsychiatry Clin Neurosci 2012, 24(1):5-15.

43. Eyles DW, Smith S, Kinobe R, Hewison M, McGrath JJ: Distribution of the vitamin $D$ receptor and 1 alpha-hydroxylase in human brain. $J$ Chem Neuroanat 2005, 29(1):21-30.

44. Eyles DW, Burne TH, McGrath JJ: Vitamin D, effects on brain development, adult brain function and the links between low levels of vitamin $D$ and neuropsychiatric disease. Front Neuroendocrinol 2013, 34(1):47-64.

45. Carlsson A: A half-century of neurotransmitter research: impact on neurology and psychiatry (Nobel lecture). Chembiochem 2001, 2(7-8):484-493.

46. Groves NJ, Kesby JP, Eyles DW, McGrath JJ, Mackay-Sim A, Burne TH: Adult vitamin $D$ deficiency leads to behavioural and brain neurochemical alterations in C57BL/6 J and BALB/c mice. Behav Brain Res 2013, 241:120-131.

47. Lewis DA, Moghaddam B: Cognitive dysfunction in schizophrenia: convergence of gamma-aminobutyric acid and glutamate alterations. Arch Neurol 2006, 63(10):1372-1376.

48. Riaza Bermudo-Soriano C, Perez-Rodriguez MM, Vaquero-Lorenzo C, Baca-Garcia E: New perspectives in glutamate and anxiety. Pharmacol Biochem Behav 2012, 100(4):752-774.

49. Mohler $\mathrm{H}$ : The GABA system in anxiety and depression and its therapeutic potential. Neuropharmacology 2012, 62(1):42-53.

50. Szakacs R, Janka Z, Kalman J: The "blue" side of glutamatergic neurotransmission: NMDA receptor antagonists as possible novel therapeutics for major depression. Neuropsychopharmacol Hung 2012, 14(1):29-40.

51. Coyle JT: Substance use disorders and Schizophrenia: a question of shared glutamatergic mechanisms. Neurotox Res 2006, 10(3-4):221-233.

52. Hoogendijk WJ, Lips P, Dik MG, Deeg DJ, Beekman AT, Penninx BW: Depression is associated with decreased 25-hydroxyvitamin D and increased parathyroid hormone levels in older adults. Arch Gen Psychiatry 2008, 65(5):508-512.
53. Jorde R, Waterloo K, Saleh F, Haug E, Svartberg J: Neuropsychological function in relation to serum parathyroid hormone and serum 25hydroxyvitamin D levels: the Tromso study. J Neurol 2006, 253(4):464-470.

54. Gronli O, Wynn R: Normocalcemic hyperparathyroidism and treatment resistant depression. Psychosomatics 2013, 54:492-497.

55. Duque G, Close JJ, de Jager JP, Ebeling PR, Inderjeeth C, Lord S, McLachlan AJ, Reid IR, Troen BR, Sambrook PN: Treatment for osteoporosis in Australian residential aged care facilities: consensus recommendations for fracture prevention. Med J Aust 2010, 193(3):173-179.

56. Michael YL, Whitlock EP, Lin JS, Fu R, O'Connor EA, Gold R: US preventive services task force: primary care-relevant interventions to prevent falling in older adults: a systematic evidence review for the U.S preventive services task force. Ann Intern Med 2010, 153(12):815-825.

57. Tang BM, Eslick GD, Nowson C, Smith C, Bensoussan A: Use of calcium or calcium in combination with vitamin D supplementation to prevent fractures and bone loss in people aged 50 years and older: a metaanalysis. Lancet 2007, 370(9588):657-666.

58. Bischoff-Ferrari HA: Relevance of vitamin D in muscle health. Rev Endocr Metab Disord 2012, 13(1):71-77

59. Pfeifer M, Begerow B, Minne HW, Suppan K, Fahrleitner-Pammer A, Dobnig $\mathrm{H}$ : Effects of a long-term vitamin D and calcium supplementation on falls and parameters of muscle function in community-dwelling older individuals. Osteoporos Int 2009, 20(2):315-322

60. Bischoff-Ferrari HA, Dawson-Hughes B, Staehelin HB, Orav JE, Stuck AE, Theiler R, Wong JB, Egli A, Kiel DP, Henschkowski J: Fall prevention with supplemental and active forms of vitamin D: a meta-analysis of randomised controlled trials. BMJ 2009, 339:b3692.

61. Tuohimaa P, Keisala T, Minasyan A, Cachat J, Kalueff A: Vitamin D, nervous system and aging. Psychoneuroendocrinology 2009, 34(Suppl 1):S278-86.

62. de Abreu DA F, Eyles D, Feron F: Vitamin D, a neuro-immunomodulator: implications for neurodegenerative and autoimmune diseases. Psychoneuroendocrinology 2009, 34(1):S265-77.

63. Hutchinson MS, Grimnes G, Joakimsen RM, Figenschau Y, Jorde R: Low serum 25-hydroxyvitamin D levels are associated with increased all-cause mortality risk in a general population: the Tromso study. Eur J Endocrinol 2010, 162(5):935-942.

64. Autier $\mathrm{P}$, Boniol $\mathrm{M}$, Pizot $\mathrm{C}$, Mullie $\mathrm{P}$ : Vitamin D status and ill health: a systematic review. Lancet Diabetes Endocrinol 2014, 2(1):76-89.

65. Hansen $V$, Jacobsen BK, Arnesen E: Prevalence of serious psychiatric morbidity in attenders and nonattenders to a health survey of a general population : the Tromso health study. Am J Epidemiol 2001, 154(10):891-894.

doi:10.1186/1471-244X-14-134

Cite this article as: Grønli et al:: Vitamin D deficiency is common in psychogeriatric patients, independent of diagnosis. BMC Psychiatry 2014 14:134.

\section{Submit your next manuscript to BioMed Central and take full advantage of:}

- Convenient online submission

- Thorough peer review

- No space constraints or color figure charges

- Immediate publication on acceptance

- Inclusion in PubMed, CAS, Scopus and Google Scholar

- Research which is freely available for redistribution 